\title{
LIMITED SEED DISPERSAL MAY SHAPE GENETIC STRUCTURE OF Hydnophytum formicarum JACK. POPULATIONS IN MANGROVE ECOSYSTEM ${ }^{* *}$
}

\author{
ABDUL SHUKOR YUSOFF, WAN BAYANI WAN OMAR AND SHAHRUDIN ROHANI* \\ Faculty of Science and Marine Environment, Universiti Malaysia Terengganu, 21030 Kuala Nerus, Terengganu, Malaysia
}

Received 03 January 2019 / Accepted 22 January 2019

\begin{abstract}
Hydnophytum formicarum is an epiphytic plant, commonly distributed throughout Southeast Asia. However, its distribution is currently declining due to forest fragmentation and the subsequent habitat changes which may have also consequently affected the genetic structure of $H$. formicarum populations. Hence, this study aimed to understand the genetic variation and differentiation within and among populations of this species. Using Random Amplified Polymorphic DNA (RAPD) markers, the genetic variation and genetic differentiation among three populations were assessed in order to identify potential conservation management strategies for this species in the mangrove ecosystem in Malaysia. Ten highly reproducible primers were used in the population analysis, resulting in a total of 221 discernible fragments. Genetic variation among populations was high at $98 \%$ identified polymorphic fragments. AMOVA showed significant genetic differentiation among the populations $\left(\Phi_{\mathrm{PT}}=\right.$ $0.554, \mathrm{p} \leq 0.001$ ), with pairwise genetic distances between the populations ranging from $0.495-0.589$. PCoA clustering analysis separated the populations according to their geographical locations. The high genetic variation within a population, high genetic differentiation between populations and clear separation in the cluster analysis indicated a restricted seed dispersal of the species.
\end{abstract}

Keywords: AMOVA, epiphyte, myrmecophyte, RAPD, Setiu Wetlands

\section{INTRODUCTION}

Epiphytes are plants growing on other plants without directly harming their hosts (Zotz 2016). It is one major plant groups contributing largely to worldwide plant diversity. Vascular epiphytes alone constitute about $10 \%$ of overall global vascular floristic composition (Brown et al. 2015) and are distributed extensively across the world. Some epiphytic species have been recorded as myrmecophytes due to their association with ants (Chomicki \& Renner 2015). Epiphyte studies have also revealed that these plants are particularly sensitive to environmental and habitat changes.

Hydnophytum formicarum Jack is one epiphyte of the Rubiaceae family that is identified as a

\footnotetext{
${ }^{*}$ Corresponding author, e-mail: rohanishahrudin@umt.edu.my * This paper was presented at the 3rd International Conference on Tropical Biology 2018, 20-21 September 2018, Bogor, West Java, Indonesia
}

myrmecophyte due to its close association with ants as nesters and dispersers (Hosoishi et al. 2018). Hydnophytum formicarum is a species among 93 others in the genus Hydnophytum, under subtribe Hydnophytinae, which also considered as the world's most species-rich ant plant group (Chomicki \& Renner 2015). This species is distributed natively in Southeast Asia (Huxley 1978). Notably, the species is widely distributed in the tropical region, and no record can be found on this species in the temperate region. This species favours coastal trees, mangroves and lowland swamp savannahs and hill savannahs (Huxley 1978). Giesen et al. (2006) have described this species as a mangroveassociated species as its abundance is prominent in this ecosystem. In Singapore, $H$. formicarum has been listed as critically endangered, with few in numbers currently present and no other surviving myrmecophytic epiphytes of the Rubiaceae family (Lok \& Tan 2009). 
The association of Rubiaceous epiphytes including Hydnophytum with their ant occupants is called symbiosis or mutualism (Huxley 1980). Notably, ants of the Iridomyrmex spp. and Crematogaster spp. were found dwelling in the epiphytes domatia (Huxley 1980). Ant's occupation on the epiphytes were highly observed in parts of the plants including the stem, leaf or root of domatia (Chomicki \& Renner 2015). Ants also act as dispersers for their host epiphytes. For instance, the ant species Philidris nagasan (Dolichoderinae) was doing an obligate farming of some epiphytes from genus Squamellaria in Fiji (Chomicki \& Renner 2016). However, the epiphytes and ants mutualism can also be affected when other changes occur such as habitat shift and also the morphological changes of the host (Chomicki \& Renner 2017). Habitat deterioration and fragmentation has affected the distribution and genetic structure of the epiphyte species Crepis triasii (Asteraceae) in the Mediterranean Islands (Mayol et al. 2012) and Hedyotis chrysotricha (Rubiaceae) in China (Yuan et al. 2012). Along the east coast of Peninsular Malaysia, aggressive coastal development has affected the coastline (Muslim et al. 2011; Ahmad et al. 2014). In that same region, in the state of Terengganu, an abundance of $H$. formicarum has been observed in the coastal islands with high proclivity to be affected by the aforementioned changes. Hence, this fragmentation threat has directed the assessment of the genetic structure of $H$. formicarum on island populations along the coasts.

Studies on the genetic structure of plant's island population have discovered that their spread is in accordance with the species' geographical distribution (Oiki et al. 2001; Zhang et al. 2018). However, when there is intermixing of genetic groups, dispersers were found to normally play their roles (Godoy \& Jordano 2001; Schidegger et al. 2012). Geographical barriers and isolation by distance (IBD) of populations separated by bodies of water or oceanic barriers have been thoroughly studied (Dias et al. 2016; Levy et al. 2016) as these factors will eventually contribute to species' gene flow (Lee \& Thomas 2011). One study on the genetic structure of plant populations in an island ecosystem (Hufford et al. 2013) (discovered a strong genetic differentiation within and among island populations and apparent IBD between islands. A high variation within island populations and significant genetic differentiation among populations were also observed in the epiphytic orchids (Mallet et al. 2014). Similarly, the geographical isolation has limited the seed and pollen dispersal of Banksia arborea in terrestrial islands (Nistelberger et al. 2015). As island populations are relatively smaller in comparison to mainland populations, the genetic variation in island populations should be less (Frankham 1996), a theory that was substantiated by Hufford et al. (2013) and Laukkanen et al. (2014).

Since no study using molecular markers has yet been conducted for $H$. formicarum, this study aimed to investigate the genetic variation and differentiation within and among populations for this species as these will provide basic information for management plans focusing in the conservation of this species. Specifically, this study will determine and compare the genetic variation of this species in Pulau Telaga Tujuh, Pulau Layat and Pulau Redang populations.

\section{MATERIALS AND METHODS}

\section{Plant Sampling}

Leaves were sampled from 21 individual plants (one leaves per individual), of the 7 individual plants from each of the three different island mangrove forests in Terengganu on the east coast of Peninsular Malaysia. Pulau Telaga Tujuh (PT) and Pulau Layat (PL) are nearby small mangrove islands, while Pulau Redang (PR) is a tourism island with a fragmented mangrove ecosystem located in the district of Kuala Terengganu, approximately 30 $\mathrm{km}$ away from Setiu Wetlands (Fig. 1). Each H. formicarum leaf was collected from different phorophytes. Leaves were preserved in zip-lock bags with silica gel and then frozen in $-20{ }^{\circ} \mathrm{C}$ conditions prior to genetic material extraction.

\section{Molecular Analysis}

DNA was extracted from the frozen leaf samples using modified CTAB method (Doyle \& Doyle 1990) after leaf grinding into lyophilized form using liquid nitrogen. The DNA concentration was estimated using 
BioDrop (Denville Scientific) spectrophotometer. Ten out of 20 screened universal RAPD (Random Amplified Polymorphic DNA) primers by Operon Technologies were chosen in this study (Table 1). The reproducibility of the selected primers was ensured by replicating the amplification process during optimization.

Genomic DNA was amplified in a reaction volume of $20 \mu \mathrm{L}$ consisting of template DNA, $1 \mathrm{X}$ reaction buffer (Promega), $2 \mathrm{mM} \mathrm{MgCl}_{2}$ (Promega), $0.1 \mathrm{mg} / \mathrm{mL}$ BSA (Promega), 0.25 mMdNTPs (Promega), $0.25 \mu \mathrm{M}$ of each primer $\left(\mathrm{OPA}, 1^{\text {st }}\right.$ Base) and 0.5 units of Taq polymerase (Promega). The DNA was amplified using thermocycler (Applied Biosystems) at 30 and 45 cycles for $180 \mathrm{sec}$ of initial denaturation and then $30 \mathrm{sec}$ of denaturation at $95{ }^{\circ} \mathrm{C}, 30 \mathrm{sec}$ annealing temperature at $32.6{ }^{\circ} \mathrm{C}$ to $37.7{ }^{\circ} \mathrm{C}, 60$ $\mathrm{sec}$ of extension and then $420 \mathrm{sec}$ of final extension at $72{ }^{\circ} \mathrm{C}$. The PCR products were electrophoresed in 1.5\% Agarose gel and TBE buffer and ran for $90 \mathrm{~min}$ at $60 \mathrm{~V}$. The gel was then stained using Diamond ${ }^{\circledR}$ Nucleic Acid dye (Promega) and was finally visualized and photographed using the Bio Rad gel documentation system.

\section{Data Analyses}

The amplified fragments were scored as 1 if present and 0 if absent and then assembled into a data matrix. The Principal Coordinate Analysis (PCoA) cluster analysis based on genetic distance was performed using PAST 3 software (Hammer et al. 2001). Analysis of the molecular variance (AMOVA) (Excoffier et al. 1992) was used to partition the total genetic diversity between and among populations. The population genetic differentiation indicator, pairwise $\Phi_{\text {PT }}$ of AMOVA, was also calculated. AMOVA and pairwise $\Phi_{\mathrm{PT}}$ were both performed using GENALEX V6.1 (Peakall \& Smouse 2006).

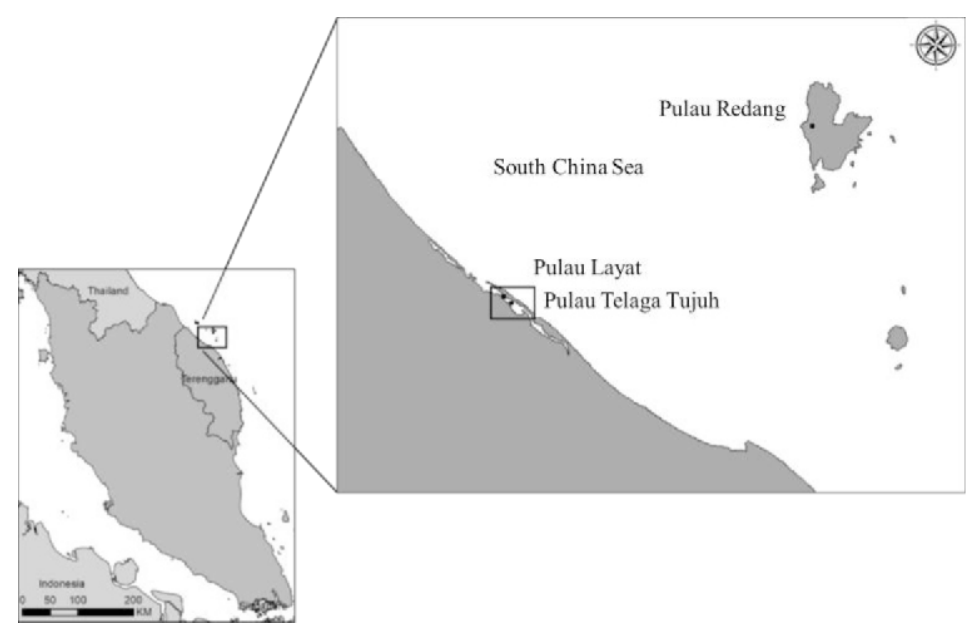

Figure 1 Map of the Hydnophytum formicarum populations in Terengganu

Table 1 Primer names and sequences chosen for PCR

\begin{tabular}{ccccc}
\hline No. & Primer name & $\begin{array}{c}\text { Primer sequence } \\
5^{\prime} \text { to 3' }\end{array}$ & $\begin{array}{c}\text { Nucleotide length } \\
\text { C+G content } \\
(\%)\end{array}$ \\
\hline 1 & OPA-01 & CAGGCCCTTC & 10 -mer & 70.0 \\
2 & OPA-03 & AGTCAGCCAC & 10 -mer & 60.0 \\
3 & OPA-05 & AGGGGTCTTG & 10 -mer & 60.0 \\
4 & OPA-07 & GAAACGGGTG & $10-$ mer & 60.0 \\
5 & OPA-09 & GGGTAACGCC & $10-$ mer & 70.0 \\
6 & OPA-11 & CAATCGCCGT & $10-$ mer & 60.0 \\
5 & OPA-13 & CAGCACCCAC & $10-$ mer & 70.0 \\
8 & OPA-15 & TTCCGAACCC & $10-$ mer & 60.0 \\
9 & OPA-17 & GACCGCTTGT & $10-$ mer & 60.0 \\
10 & OPA-19 & CAAACGTCGG & $10-$ mer & 60.0 \\
\hline
\end{tabular}




\section{RESULTS AND DISCUSSION}

\section{Genetic Variation}

A total of 221 discernible fragments (Fig. 2) from the 21 individual plants of $H$. formicarum were produced at an average of 22.1 fragments per primer. The amplified fragment sizes ranged from 150 to 2500 base pairs (bp).

Using the primer OPA17, the fragments showed 98\% polymorphism, with Pulau Telaga Tujuh scoring the highest percentage $(89.5 \%)$, followed by Pulau Redang (78.11\%) and Pulau Layat $(60.11 \%)$ (Table 2) indicating that Pulau Telaga Tujuh has the highest genetic variation since a high percentage of polymorphism in a population means a high genetic variation (Oiki et al. 2001; Boneh et al. 2003). Moreover, genetic variation is positively correlated with population size (Frankham 1996). This high genetic variation was also found within the island population of epiphytic orchids (Mallet et al. 2014). The Principal Coordinate Analysis (PCoA) further showed that the individuals from the three different populations were genetically different (Fig. 3).

Furthermore, the RAPD marker confirmed the genetic variation among the plants' population (Monaghan \& Halloran 1996). The percentage of polymorphism in Pulau Redang, an island located at sea, was 18\% higher than Pulau Layat even though Pulau Layat was located just meters away from Pulau Telaga Tujuh, which had the highest polymorphism percentage. The relatively low genetic variation in Pulau Redang compared to Pulau Telaga Tujuh is possibly due to its oceanic location, which may have limited the gene flow from the mainland resources (Maki 2001). Islands that are closer to mainland, like Pulau Telaga Tujuh are more likely to act as allelic sink (Curto et al. 2017). Presumably, Pulau Layat is a newly established population, considering its low genetic variation and possibly genetic diversity (Hagen \& Hamrick 1998). Since the lowest polymorphism percentage was in this population, it is considered as newly founded (Ouborg et al. 1999). However, in this study, no further investigation was done to validate the reasons for the low genetic variation in Pulau Layat.

The PCoA cluster analysis exhibited that the individuals were grouped in accordance with the populations where the samples were collected. The results from this study suggest that gene flow between populations was highly restricted. Geographical barriers that have formed may have impeded the dispersal of seeds, ultimately preventing the gene flow from occurring in a wider region (Monaghan \& Halloran 1996). However, the epiphytic ferns of Hawaiian Islands were generally not genetically distinct between island populations, possibly due to high interisland gene flow (Ranker 1992). In contrast, the epiphytic orchids sampled from island populations in Puerto Rico, Dominican Republic and Cuba, had patterns of genetic variation more similar within the islands than with populations of other islands (Ackerman \& Ward 1999). A study on the Jumellea epiphytic orchid also showed that the genetic variation between two islands populations differed significantly (Blambert et al. 2016).

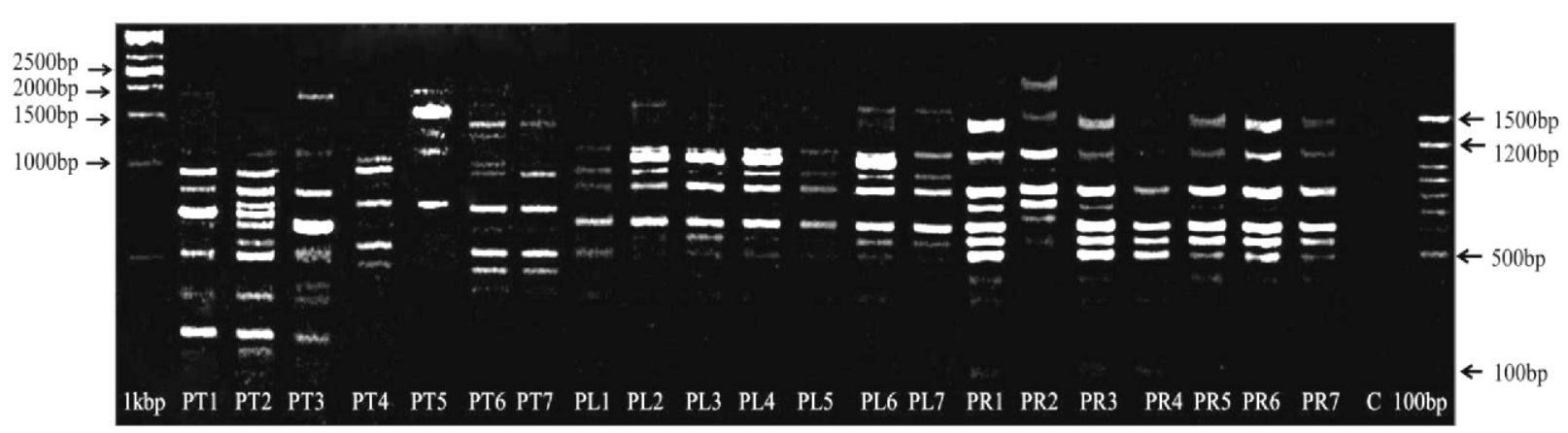

Figure 2 Photograph of Diamond ${ }^{\circledR}$ stained agarose gel of RAPD fragments using primer OPA 17 DNA samples from Pulau Telaga Tujuh (PT), Pulau Layat (PL) and Pulau Redang (PR)

Note: Lanes $1 \mathrm{kbp}$ and $100 \mathrm{bp}$ are the markers, while lane $\mathrm{C}$ is the control. 
Table 2 Genetic variability estimates for populations of $H$. formicarum from RAPD analysis

\begin{tabular}{|c|c|c|c|c|c|c|c|}
\hline No. & Code & Locality & $\mathrm{N}$ & $\mathrm{n}$ & $\begin{array}{l}\text { No. of } \\
\text { loci }\end{array}$ & $\begin{array}{c}\text { No. of } \\
\text { polymorphic } \\
\text { loci }\end{array}$ & $\begin{array}{c}\% \text { of } \\
\text { polymorphism }\end{array}$ \\
\hline 1. & PT & Pulau Telaga Tujuh & $>3000$ & 7 & 137 & 123 & 89.05 \\
\hline 2. & PL & Pulau Layat & $>100$ & 7 & 101 & 65 & 60.11 \\
\hline 3. & PR & Pulau Redang & 7 & 7 & 121 & 99 & 78.11 \\
\hline
\end{tabular}

Notes: $\mathrm{N}=$ estimated population size; $\mathrm{n}=$ number of sampled individual plants of $H$. formicarum.

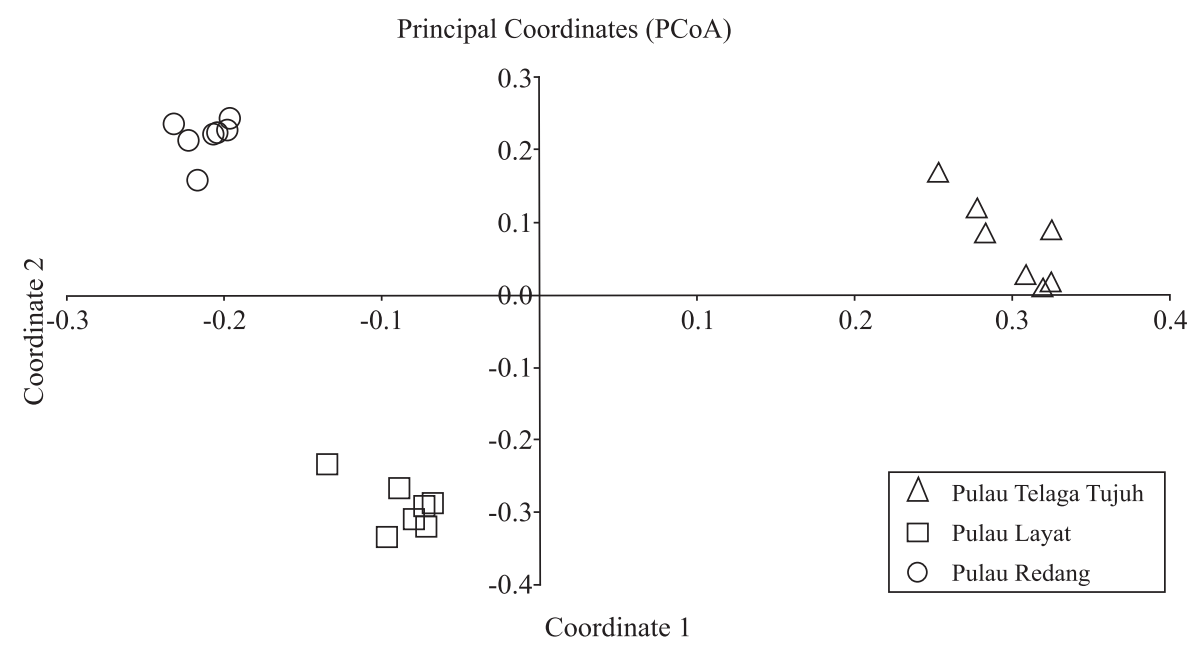

Figure 3 PCoA plot based on RAPD variations amongst populations

\section{Genetic Differentiation between Populations}

The analysis of molecular variance (AMOVA) performed on the three different populations showed that the percentage of variations amongst populations $(55 \%)$ were higher than the percentage of variation within populations $(45 \%)$ with $\mathrm{PhiPT}=0.554(\mathrm{p}=$ 0.001; 999 permutations) (Table 3).
Based on the pairwise PhiPT statistics (modified version of Wright's F), the highest variation was observed between population Pulau Layat and Pulau Redang (0.589), followed by that between Pulau Layat and Pulau Telaga Tujuh (0.584) and finally that between Pulau Telaga Tujuh and Pulau Redang (0.495) (Table 4). Greater PhiPT values indicated greater variation.

Table 3 Analysis of molecular variance (AMOVA) within and among the three populations of H. formicarum

\begin{tabular}{ccccccc}
\hline Source of variation & $\mathrm{df}$ & SS & MS & Est. var. & $\%$ & $\mathrm{p}$ \\
\hline Among populations & 2 & 387.52 & 193.76 & 24.82 & $55 \%$ & 0.001 \\
Within populations & 18 & 359.42 & 19.96 & 19.96 & $45 \%$ & 0.001 \\
Total & 20 & 746.94 & & 44.78 & $100 \%$ & \\
\hline
\end{tabular}

Table 4 Pairwise population PhiPT values $\left(\Phi_{\mathrm{PT}}\right)$

\begin{tabular}{cccl}
\hline Pulau Telaga Tujuh & Pulau Layat & Pulau Redang & \\
\hline 0.000 & 0.584 & 0.495 & Pulau Telaga Tujuh \\
0.584 & 0.000 & 0.589 & Pulau Layat \\
0.495 & 0.589 & 0.000 & Pulau Redang \\
\hline
\end{tabular}


AMOVA values signified high genetic differentiations, both between and within populations, with $\Phi_{\text {PT }}$ values higher than 0.25 . Genetic differentiations also existed among Indian epiphytic orchids (Nagananda et al. 2012). Similarly, a study on epiphytic Bromeliads $V$ riesea scalaris and V riesea simplex, showed high genetic differentiations between and within populations of $V$. scalaris (Neri et al. 2017). The high genetic differentiation between populations and clear separation in cluster analysis indicated a restricted seed dispersal of $H$. formicarum (Nieder et al. 2000; Mucciarelli et al. 2014), and this restricted seed dispersal could lead to fine scale genetic differentiation and restricted gene flow (Theim et al. 2014). In our study, the geographical distance and isolation may have affected the gene flow (Ouborg et al. 1999; Rousset 2000). However, a low genetic differentiation among three different island populations of Cephalantera rubra (Brzosko \& Wróblewska 2003) was possibly due to short distances between the islands. Hence, no barrier for gene flow existed, as the populations probably originated from the same source. The low genetic differentiation among populations of the hemi-epiphytic species Ficus pumila L. in southern China, including several islands, suggested the success of pollinators in dispersal (Liu et al. 2015).

The relationship between Hydnophytum formicarum and ants is considered a facultative mutualistic type, where ants take charge of protecting the plants from phytophagus animals and other abiotic and biotic threats, while plants provide them with a food source, nesting space or sometimes both (Heil 2010). Once the plant is disturbed, the ants will swarm and fend off the threats. Many ant plant species have adapted their caudexes or tubers and provided shelter and protection for the ant colony associated with them (Heil 2010; Richards \& Coley 2012; González-Teuber et al. 2014).

This mutualism has limited the seed dispersal of $H$. formicarum almost exclusively to ants as dispersers. The pattern of seed dispersal indeed can shape the genetic structure and composition of plant populations (Hamrick et al. 1993). On top of the geographical barrier and the isolation separating the populations, conceivably, ants were unable to cross the water between islands, over time limiting the seed dispersal of
H. formicarum. Higher genetic variation found within populations suggests that long distance dispersal by migrating birds has contributed to the variation (Zarek 2009). However, even if some flying birds were able to consume the fruit of H. formicarum (Lok \& Tan 2009), the number and frequency of such incidents are still low because of the ants that protect the species, making it difficult for the birds to feed on the species' fruit.

The relationship between $H$. moseleyanum and Pbilidris ants however, proved that ants' behavior has resulted in the population structure changes of $H$. moseleyanum (Maeyama \& Matsumoto 2000). Territorial Philidris ants which aggressively attack ants from different colony could possibly result in the dispersal of $H$. moseleyanum seeds restricted only to a colony. A similar phenomenon could have happened in the restricted seed dispersals of $H$. formicarum in this study and may have eventually shaped its genetic structure. Seeds dispersal by ants generated a local spatial genetic structure (Peakall \& Beattie 1995). In other studies, the genetic structure of some plants were also found to be promoted by ants (Yao 2010; Pérez-Collazos et al. 2015).

\section{CONCLUSION}

Seed dispersal was limited due to geographical barriers, yet the role of ants as agents of dispersal, shed light on the changes of $H$. formicarum's genetic structure and its high abundance in three mangrove forests. Seeds movement by ants have structured the genetic population of $H$. formicarum in these 3 islands. The limitation of ants as being agents of dispersal, if not halted, curbed the gene flow occurrence among populations. This study served as the first step in evaluating conservation strategies for this species and in assisting conservation efforts particularly, on the genetic variation of the $H$. formicarum populations.

\section{ACKNOWLEDGEMENTS}

This research was supported by Niche Research Grant Scheme (NRGS) (Vot no. $53131 / 12$ ) from Ministry of Education (MOE), Malaysia. 


\section{REFERENCES}

Ackerman JD, Ward S. 1999. Genetic variation in a widespread, epiphytic orchid: Where is the evolutionary potential? Syst Bot 24(2):282-91.

Ahmad MF, Yaacob R, Mamat M, Muslim AM, Husain ML. 2014. Coastline changes in vicinity of runway platform of Sultan Mahmud Airport, Kuala Terengganu: Comparative analysis of oneline model versus satellite data. J Appl Sci 14(19):22-34.

Blambert L, Mallet B, Humeau L, Pailler T. 2016. Reproductive patterns, genetic diversity and inbreeding depression in two closely related Jumellea species with contrasting patterns of commonness and distribution. Ann Bot 118(1):93-103.

Boneh L, Kuperus P, Van Tienderen PH. 2003. Microsatellites in the bromeliads Tillandsia fasciculata and Gurmania monostachya. Mol Ecol Notes 3(2):302-3.

Brown M, Mariscal A, Chinchero MA, Diaz A. 2015. Biotic factors affecting the abundance of vascular epiphytic bromeliads growing in cloud forest in Reserva Biologica Los Cedros, Ecuador. Ann Res Rev Biol 6(6): 355-63.

Brzosko E, Wróblewska A. 2003. Genetic variation and clonal diversity in island Cephalanthera rubra populations from the Biebrza National Park, Poland. Bot J Linn Soc 143(1):99-108.

Chomicki G, Renner SS. 2015. Phylogenetics and molecular clocks reveal the repeated evolution of ant plants after the late Miocene in Africa and the early Miocene in Australasia and the Neotropics. New Phytol 207(2):411-24.

Chomicki G, Renner SS. 2016. Obligate plant farming by a specialized ant. Nat Plants 2(12):16181.

Chomicki G, Renner SS. 2017. Partner abundance controls mutualism stability and the pace of morphological change over geologic time. PNAS 114(15):3951-6.

Curto M, Puppo P, Kratschmer S, Meimberg H. 2017. Genetic diversity and differentiation patterns in Micromeria from the Canary Islands are congruent with multiple colonization dynamics and the establishment of species syngameons. BMC Evol Biol 17(1):1-16.

Dias EF, Moura M, Schaefer H, Silva L. 2016. Geographical distance and barriers explain population genetic patterns in an endangered island perennial. AoB PLANTS 8:1-17.

Doyle JJ, Doyle JL. 1990. Isolation of plant DNA from fresh tissue. Focus 12:13-5.

Excoffier L, Smouse PE, Quattro JM 1992. Analysis of molecular variance inferred from metric distances among DNA haplotypes: Application to human mitochondrial DNA restriction data. Genetics 131:479-91.

Frankham R. 1996. Relationship of genetic variation to population size in wildlife. Conserv Biol 10(6): 1500-8.

Giesen W, Wulffraat S, Zieren M, Scholten L. 2006. Mangrove guidebook for Southeast Asia. Bangok (TH): RAP PUBLICATION.

Godoy JA, Jordano P. 2001. Seed dispersal by animals: Exact identification of source trees with endocarp DNA microsatellites. Mol Ecol 10(9):2275-83.

González`Teuber M, Kaltenpoth M, Boland W. 2014. Mutualistic ants as an indirect defence against leaf pathogens. New Phytol 202(2):640-50.

Hagen MJ, Hamrick JL. 1998. Genetic variation and population genetic structure in Trifolium pratense. J Hered 89(2):178-81.

Hammer Ø, Harper DA, Ryan PD. 2001. PAST: Paleontological statistics software package for education and data analysis. Palaeontol Electron 4(1):1-9.

Hamrick JL, Murawski DA, Nason JD. 1993. The influence of seed dispersal mechanisms on the genetic structure of tropical tree populations. Vegetatio 107(108):281-97.

Heil M. 2010. Ant-plant mutualisms. In: Encyclopedia of Life Sciences (ELS). Chichester (UK): John Wiley \& Sons.

Hosoishi S, Park S, Tagane S, Rahman MM, Ogata K. 2018. Domatia of the ant-plant Hydnophytum formicarum (Rubiaceae) captured as nests by two widespread ant species, Tapinoma melanocephalum and Tetramorium nipponense (Hymenoptera: Formicidae). Entomol News 127(5):407-12.

Hufford KM, Mazer SJ, Hodges SA. 2013. Genetic variation among mainland and island populations of a native perennial grass used in restoration. AoB PLANTS 6:1-12.

Huxley CR. 1978. The ant-plants Myrmecodia and Hydnophytum (Rubiaceae), and the relationship between their morphology, ant occupants, physiology, and ecology. New Phytol 80:231-68.

Huxley CR. 1980. Symbiosis between ants and epiphytes. Biol Rev 55(3):321-40.

Laukkanen L, Mutikainen P, Muola A, Leimu R. 2014. Plant-species diversity correlates with genetic variation of an oligophagous seed predator. PLOS ONE 9(4):1-9.

Lee CRR, Thomas MO. 2011. Quantifying effects of environmental and geographical factors on patterns of genetic differentiation. Mol Ecol 20(22):4631-42. 
Levy E, Byrne M, Coates DJ, Macdonald BM, McArthur S, Van Leeuwen S. 2016. Contrasting influences of geographic range and distribution of populations on patterns of genetic diversity in two sympatric Pilbara acacias. PLoS ONE 11(10):1-18

Liu M, Compton SG, Peng FE, Zhang J, Chen XY. 2015. Movements of genes between populations: are pollinators more effective at transferring their own or plant genetic markers? P Roy Soc B-Biol Sci 282:1-11.

Lok AFSL, Tan HT. W. 2009. Tuberous, epiphytic, rubiaceous myrmecophytes of Singapore. Nature in Singapore 2:231-6.

Maeyama T, Matsumoto T. 2000. Colonial system of Philidris ants (Formicidae; Dolichoderinae) occupying epiphytic myrmecophytes in a tropical mangrove forest. Trop Ecol 41(2):209-16.

Maki M. 2001. Genetic differentiation within and among island populations of the endangered plant Aster miyagii (Asteraceae), an endemic to the Ryukyu Islands. Am J Bot 88(12):2189-94.

Mallet B, Martos F, Blambert L, Pailler T, Humeau L. 2014. Evidence for isolation-by-habitat among populations of an epiphytic orchid species on a small oceanic island. PLoS ONE 9(2):1-12.

Mayol M, Palau C, Rosselló JA, González-Marítnez CS, Molins A, Riba M. 2012. Patterns of genetic variability and habitat occupancy in Crepis triasii (Asteraceae) at different spatial scales: Insights on evolutionary processes leading to diversification in continental islands. Ann Bot $109(2): 429-41$.

Monaghan BG, Halloran GM. 1996. RAPD variation within and between natural populations of morama [Tylosema esculentum (Burchell) Schreiber] in southern Africa. S Afr J Bot 62(6):287-91.

Mucciarelli M, Ferrazzini D, Belletti P. 2014. Genetic Variability and population divergence in the rare Fritillaria tubiformis subsp. moggridgei Rix (Liliaceae) as revealed by RAPD Analysis. PLoS ONE $9(7): 1-8$.

Muslim AM, Ismail KI, Razman N, Zain K, Khalil I. 2011. Detection of shoreline changes at Kuala Terengganu, Malaysia from multi-temporal satellite sensor imagery. In: $34^{\text {th }}$ International Symposium on Remote Sensing of Environment. Proceedings: 2011 Apr 15-10.

Nagananda GS, Chetana GR, Rajath S, Suryan S, Sundara RS. 2012. Assessment of genetic variation among three species of aerides an epiphytic orchid from Western Ghats, India using RAPD markers. Int J Pharma Bio Sci 3(3):682-8.

Neri J, Wendt T, Palma-Silva C. 2017. Natural hybridization and genetic and morphological variation between two epiphytic bromeliads. AoB PLANTS 10(1):1-16.
Nieder J, Engwald S, Klawun M, Barthlott W. 2000. Spatial distribution of vascular epiphytes (including hemiepiphytes) in a Lowland Amazonian Rain Forest (Surumoni crane plot) of Southern Venezuela. Biotropica 32(3):385-96.

Nistelberger HM, Byrne M, Coates D, Roberts JD. 2015. Phylogeography and population differentiation in terrestrial island populations of Banksia arborea (Proteaceae). Biol J Linn Soc 114:860-72.

Oiki S, Kawahara T, Inoue K, Ohara M, Maki M. 2001. Random amplified polymorphic DNA (RAPD) variation among populations of the insular endemic plant Campanula microdonta (Campanulaceae). Ann Bot 87(5):661-7.

Ouborg NJ, Piquot Y, Van Groenendael JM. 1999. Population genetics, molecular markers and the study of dispersal in plants. J Ecol 87:551-68.

Peakall R, Beattie AJ. 1995. Does ant dispersal of seeds in Sclerolaena diacantha (Chenopodiaceae) generate local spatial genetic structure? Heredity 75(4):351-61.

Peakall R, Smouse PE. 2006. GENALEX 6: Genetic analysis in Excel. Population genetic software for teaching and research. Mol Ecol Notes 6:288-95.

Pérez-Collazos E, Segarra-Moragues JG, Villar L, Catalán P. 2015. Ant pollination promotes spatial genetic structure in the long-lived plant Borderea pyrenaica (Dioscoreaceae). Biol J Linn Soc 116(1):144-55.

Ranker TA. 1992. Genetic diversity of endemic Hawaiian epiphytic ferns: Implications for conservation. Selbyana 13:131-7.

Richards LA, Coley PD. 2012. Domatia morphology and mite occupancy of Psychotria horizontalis (Rubiaceae) across the Isthmus of Panama. Arthropod-Plant Inte 6(1):129-36.

Rousset F. 2000. Genetic differentiation between individuals. J Evol Biol 13(1):58-62.

Scheidegger C, Bilovitz PO, Werth S, Widmer I, Mayrhofer H. 2012. Hitchhiking with forests: Population genetics of the epiphytic lichen Lobaria pulmonaria in primeval and managed forests in southeastern Europe. Ecol Evol 2(9):2223-40.

Theim TJ, Shirk RY, Givnish TJ. 2014. Spatial genetic structure in four understory Psychotria species (Rubiaceae) and implications for tropical forest diversity. Am J Bot 101(7):1189-99.

Yao I. 2010. Contrasting patterns of genetic structure and dispersal ability in ant-attended and nonattended Tuberculatus aphids. Biol Lett 6(2):2826.

Yuan N, Comes HP, Mao YR, Qi XS, Qiu YX. 2012. Genetic effects of recent habitat fragmentation in the Thousand-Island Lake region of southeast China on the distylous herb Hedyotis chrysotricha (Rubiaceae). Am J Bot 99(10):1715-25. 
Zarek M. 2009. RAPD Analysis of genetic structure in four natural populations of Taxus baccata from Southern Poland. Acta Biol Cracov Bot 51(2): 67-75.

Zhang Z, Xie W, Zhang J, Zhao X, Zhao Y, Wang Y. 2018. Phenotype- and SSR-based estimates of genetic variation between and within two important Elymus species in Western and Northern China. Genes 9(147):1-18.

Zotz G. 2016. Plants on plants - The biology of vascular epiphytes. Basel $(\mathrm{CH})$ : Springer. 